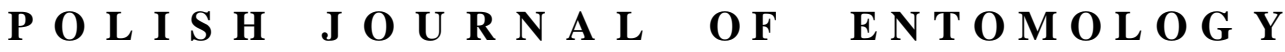

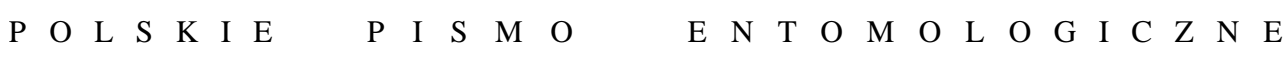

VOL. 85: 339-354

Lublin

30 September 2016

DOI: $10.1515 /$ pjen-2016-0019

\section{Contribution to the study of longhorns from New Caledonia, VI. Revision of the tribe Amphoecini BREUNING, 1951 (Coleoptera, Cerambycidae, Cerambycinae)}

\author{
EDUEARD VIVES ${ }^{1 *}$, JÉRÔME SUDRE ${ }^{2}$ \\ ${ }^{1}$ Museu de Ciències Naturals de Barcelona, Departament d'Artròpodes, \\ Passeig Picasso s/n. P.O. Box 593, Spain \\ ${ }^{2} 24$ rue de la Villette, 34570 Pignan, France
}

\begin{abstract}
In this work the representatives of the tribe Amphoecini are revised. One new species, Amphoecus wanati sp. n., is described. The synonymy of A. metallicus and Cyananphoecus cyaneus is proposed. Finally, the New Zealand taxon, Gnomodes piceus, is moved from the tribe Aphneopini to the tribe Amphoecini.

KEY WORDS: Coleoptera, Cerambycidae, Cerambycini, tribe Amphoecini. Amphoecus metallicus, Cyananphoecus cyaneus, Gnomodes piceus, New Caledonia, New Zealand.
\end{abstract}

\section{INTRODUCTION}

The tribe Amphoecini was described by BREUNING (1951) in order to include the genera Amphoecus MontrouZIER, 1861 and Cyananphoecus BreUning, 1951. At that time each genus comprised only a single species - Amphoecus metallicus MONTROUZIER, 1861 and Cyananphoecus cyaneus (FAUVEL, 1906). Both species originate from New Caledonia and they were placed amongst the representatives of the tribe Gnomini THOMSON, 1864, in the subfamily Laminae, by various authors, LACORDAIRE (1869), HELLER (1917), AURIVILLIUS (1922), BREUNING (1945, 1962) and HAYASHI (1961), until SUDRE et al. (2010) proposed placing them amongst the representatives of the tribes of the subfamily Cerambycinae. During this study of the cerambycid species of New Caledonia, we observed that the

\footnotetext{
*Corresponding author: eduard_vives@hotmail.com
} 
endemic New Zealand cerambycid, Gnomodes piceus Broun, 1893, also belongs to the tribe Amphoecini, not to the tribe Aphneopini as historically assumed (AURIVILLIUS, 1922). It is for this reason that in the present study we propose moving it to the tribe Amphoecini, owing to the proximity of its morphology to the two known genera of this tribe and to its matching morphological characters. Finally, we propose that Cyananphoecus cyaneus is a synonym of Amphoecus metallicus because the characters used for their taxonomic separation correspond exclusively to the sexual differences existing in this species.

\section{Acknowledgements}

We are grateful for the indispensable collaboration of Dr Alain DRUMONT (IRSNB, Bruxelles), Dr Marek Wanat (MNHNU, Wrocław), Ms. Azadeh Taghavian (MNHN, Paris), Dr Geoff Monterth (QMNH, Queensland), Dr Richard LeSCHEN (NZAC, Auckland) and Dr Max BARCLAY (NHM, London), without whose assistance this revision would not have been possible.

\section{MATERIALS AND METHODS}

The specimens were examined using classical macroscopic morphological taxonomy methods. All the pictures were taken using a CANON EOS 20D digital camera, with a Canon EF 100m-F/2,8 macro lens. All measurements are given in mm.

The specimens are deposited in the following collections:

CJS : Collection Jérôme SUDRE, Montpellier, France,

IAC : Institut Agronomique calédonien, La Foa, Nouvelle-Calédonie,

IRSNB : Institut Royal des Sciences Naturelles de Belgique, Bruxelles, Bruxelles,

MNHNU : Museum of Natural History, National University Wrocław, Poland

MNHN : Muséum National d'Histoire Naturelle, Paris, France,

QMNH : Queensland Museum of Natural History, Australia,

NZAC : New Zealand Arthropod Collection, Auckland, New Zealand,

NHM : Natural History Museum, London, UK. 


\section{SYSTEMATICS}

Tribe Amphoecini Breuning, 1951, Bull. Inst. Sc. Nat Belg., 27(32): 6.

Type genus. - Amphoecus MONTROUZIER, 1861

Description. - Body short and broad, head rhomboidal with a broad neck behind. Eyes slightly convex and barely emarginated, not surrounding the broadly separated antennal insertions. Long slender palpi, the last segment dilated and oblique at apex. Long slender antennae, overreaching apex of elytra in males, scape pyriform and very rounded at the apex, length variable in the different genera.

Pronotum cylindrical, narrowed in the anterior third and slightly widened in the middle. Procoxae subconical and protruding, prosternal process laminate, procoxal cavities open behind. Short broad elytra, humeri straight and prominent, longitudinally grooved by strong punctures and rounded at the apex. Short slender legs with femora slightly dilated in the middle and straight tibiae, protarsi somewhat dilated in males. Claws divaricate.

Hind wings present but reduced, venation much simplified, MP1 very short, CuA2, AA3, cubital cell present but very narrow, medial vein well developed and a small anal vein (Fig. 14).

Remarks. - The tribe Amphoecini comprises two genera: Amphoecus MontrouZIER, 1861 from New Caledonia, and Gnomodes BRoun, 1893 from New Zealand.

\section{Key to the genera}

1. Scape shorter than twice the length of the third antennal segment. Pronotum distinctly longer than wide. Elytral interstriae rib-like in the posterior half. Head neither punctate dorsally nor striate ventrally. Legs and scape bearing the habitual short setae. ........ ........................................ Gnomodes Broun, 1893.

- Scape three times longer than the third antennal segment. Pronotum almost as long as wide. Elytral interstriae not rib-like. Head densely punctate dorsally and grooved ventrally. Legs and scape bearing long brown setae, as well as the habitual short pubescence. . Amphoecus MONTROUZIER, 1861. 
Genus Gnomodes Broun, 1893

Gnomodes Broun, 1893: 1282

Gnomodes: AURIVILLIUS, 1922: 156.

Gnomodes: LESCHEN et al., 2003: 24.

Type species. - Gnomodes piceus BROUN, 1893.

Description. - Head large, rhomboidal, widest at the level of the eyes, entire surface strongly punctate, longitudinally furrowed. Eyes not very prominent, large faceted. Palpi short with the last segment dilated and obliquely truncate. Antennae long and slender, almost reaching elytral apex in males, first antennal segment pyriform.

Pronotum cylindrical, rather shiny and with transverse striae dorsally, sides sinuate. Elytra parallel, slightly rounded beyond the apical third; discal region flattened, bearing eight longitudinal ribs separated by a series of deep rounded punctures. Short slender legs, femora dilated in the middle, tibiae straight, male protarsi slightly dilated and flattened.

Remarks. - In his description, Broun (1893) related this species to the genus Gnoma FABRICIUS, 1801, (hence the name of the genus) and suggested that it should be placed beside the New Zealand genus Zorion PASCOE, 1867 (Aphneopini), where it had previously been placed by AuRIVILLIUS (1922). We propose, as we have done previously, that the genus Gnomodes should be placed in the tribe Amphoecini, as described by BREUNING (1951).

The genus Gnomodes comprises a single species endemic to New Zealand.

Gnomodes piceus BROUN, 1893 (Fig. 1)

Gnomodes piceus BROUN, 1893: 1282.

Gnomodes piceus: HUTTON 1904: 193

Gnomodes piceus: AURIVILLIUS, 1922: 156.

Materials examined. - One female Holotype from Wellington, George V. HuDSON leg. (ex-coll. Thomas BRoun, NHM, London); one female from New Zealand WN., Taranua Ra, Dundas Hut ridge, 950 m, 3-XII-1984, R.C. CRAW leg. (NZAC, 05042499); one male from New Zealand Ohakune, 16-XII-1961, G. KUSCHEL leg. (NZAC, 040802493); one female from Wellington, G.V. HADSON leg. (NZAC, 04082494); one female from Makara, 5-XI-1924, (NZAC, 04082502). 

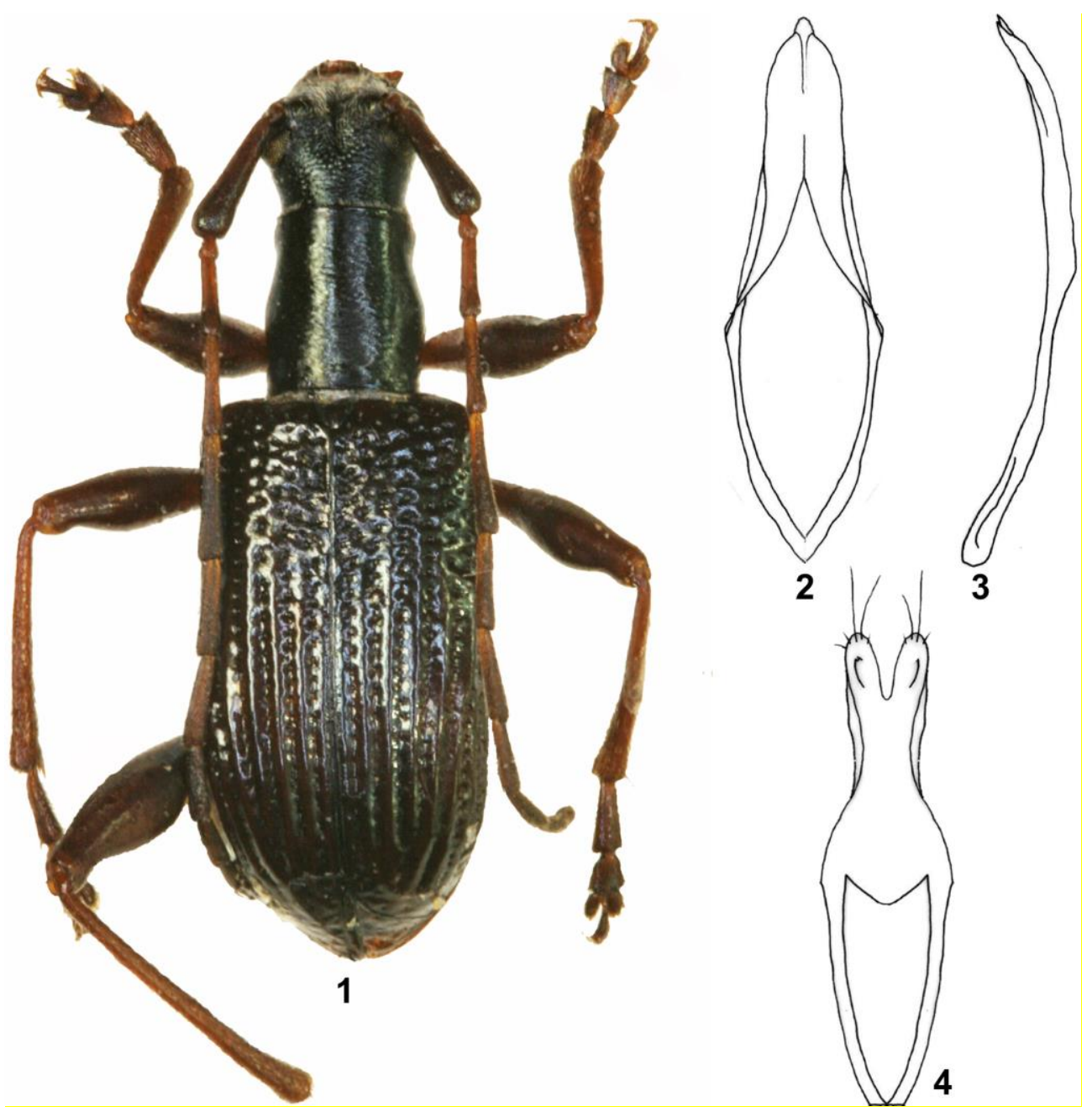

Figs. 1-4. Gnomodes piceus BROUN, 1893: 1 - male, 2 - aedeagus, ventral view, 3 - aedeagus, lateral view, 4 - tegmen, dorsal view.

Description. - Length 6-7 $\mathrm{mm}$, width $2.5 \mathrm{~mm}$. Integuments reddish brown, head and pronotum black with green metallic reflections. Legs and antennae testaceous brown, antennal segments second to fifth with a testaceous ring.

Head large, rhomboidal, eyes feebly emarginate. Antennal bases barely indicated and broadly separated by a longitudinal groove that is covered in grey tomentum. Head slightly narrowed behind the eyes forming a broad neck. Epistome translucent; labrum trapezoidal and bearing short brown setae. Long slender antennae, segments cylindrical, almost 
reaching elytral apex in males, much shorter in females. Scape very long, reaching beyond the pronotal base, much shorter in females and pyriform so that the second antennal insertion is eccentric, placed towards the inferior border. The third antennal segment is slightly shorter than the fourth and half as long as the scape, the fifth segment is slightly longer than the fourth, segments flattened after the sixth segment and weakly dentate at the external apical angle. Ventral part of head finely punctate, smooth and shiny.

Pronotum cylindrical, slightly longer than wide (ratio: 6.5 x 5.5), anterior and posterior margins finely bordered, sides sinuate, slightly narrowed in the anterior quarter and widened in the middle. Discal region flattened, completely bare, shiny and finely striated transversally. Prosternum long and narrow, procoxal cavities strongly bordered and entirely prolonged towards the posterior border. Medial surface of prosternum bearing short silver setae. Prosternal process very narrow, laminate, not closing the procoxal cavities behind. Procoxae subconical, strongly protruding. Scutellum triangular, rounded at the apex.

Elytra short, flattened and parallel, rounded from the apical fourth. Humeri straight and prominent, elytral suture finely bordered in the apical half. Each elytron bears seven longitudinal grooves formed by large aligned punctures. The interstriae are flattened at the base and very convex in the posterior half forming weak ribs, very noticeable at the start of the lateral slope. Elytral surface almost bare, bearing only some short sparse setae in the apical area. Epipleurae wide, smooth and shiny, strongly bordered. Mesosternum very short and broad, mesosternal process with a slight ledge. Metasternum short and broad, quadrangular, smooth and shiny, bearing grey setae. Abdominal ventrites broad and short, finely punctate and covered in sparse golden tomentum. Short slender legs, covered in very sparse short golden setae. Protarsi of males are weakly dilated. Claws divaricate.

Male copulatory organ with a short, thick, slightly arched aedeagus, the apex forked medially. Endophallus without chitinised sclerites at the base or medially, with dense chitinised scales only apically. Tegmen long and slender, parameres very short and bearing very short setae at the apex, amongst these a long flagellum stands out in the distal part (Figs. 2, 3, 4).

Remarks. - Captain Thomas BRoun described this genus and species from a single female collected from a Kaori (Agathis australis (D.DON) LOUDON) log. HUDSON (1934) mentioned that it is not common, appearing from October to December, and that it has occasionally been captured by beating the flowers of Rubus australis G.FORST. 
Genus Amphoecus MONTROUZIER, 1861

Amphoecus MONTROUZIER, 1861: 274.

Amphoecus: LACORDAIRE, 1869: 367.

Amphoecus: BREUNING, 1945: 534.

Amphoecus: BREUNING, 1951: 4.

Amphoecus: BREUNING, 1962: 397.

Amphoecus: SUDRE et al., 2010: 6.

Cyananphoecus BREUNING, 1951: 5, syn. nov.

Cyananphoecus: SUDRE et al., 2010: 6.

Type species. - Amphoecus metallicus MONTROUZIER, 1861.

Description. - Head large, rhomboidal, entire surface very finely punctate. Antennal bases not very prominent broadly separated. Short broad neck, barely narrowed behind the eyes. Palpi long and slender, the last segment widened at the base, which is oblique. Antennae long and slender, reaching elytral apex in males. Scape three times longer than the third antennal segment. Teguments very shiny, black or brown, metallic reflections in males, bluish and matt in females.

Pronotum cylindrical, almost as long as wide. Elytra weakly parallel. Interstriae flattened in the basal third and very convex in the apical third. Short slender legs bearing long silky golden pubescence.

Remark. - This genus was described as being close to the Asian genus Gnoma FABRICIUS, 1801. Already LACORDAIRE (1869) expressed his doubts regarding its affiliation to the tribe Gnomini THOMSON, because of the absence of a scapular scar; he nevertheless included it to the tribe without further comment. BREUNING (1951) separated the genus and included it in the new tribe Amphoecini. The genus Cyananphoecus, described by FAUVEL (1906), corresponds to the females of the genus Amphoecus MONTROUZIER, 1861 in morphology; it is for this reason that we propose its synonymy.

As a result, the genus Amphoecus includes two species endemic to New Caledonia.

\section{Key to the species}

1. Elytra of males short (ratio: $51 \times 32$ ), broad and convex in females (ratio: $82 \times 59$ ), strongly dilated in the apical half, particularly in the posterior part of the discal region where they form a large transverse gibbosity $\ldots \ldots \ldots \ldots \ldots \ldots \ldots$. metallicus.

- Elytra of males long and parallel sided (ratio: 59 x 33), weakly dilated in females (ratio: $61 \times 35$ ), the posterior half with no discal gibbosity............. wanati sp. n. 
Amphoecus metallicus MONTROUZIER, 1861 (Fig. 5)

Amphoecus metallicus MONTROUZIER, 1861: 70

Amphoecus metallicus: LACORDAIRE, 1869: 367.

Amphoecus metallicus: FAUVEL, 1906: 70.

Amphoecus metallicus: BREUNING, 1945: 534.

Amphoecus metallicus: BREUNING, 1951: 4.

Amphoecus metallicus: BREUNING, 1962: 397.

Amphoecus metallicus: SUDRE et al., 2010: 6.

Cyananphoecus cyaneus FAUVEL, 1906: 70. syn. nov.

Cyananphoecus cyaneus, BREUNING, 1945: 535.

Cyananphoecus cyaneus: BREUNING, 1951: 6.

Cyananphoecus cyaneus: SUDRE et al. 2010: 6.

Materials examined: female HOLOTYPE of Amphoecus cyaneus FAUVEL, 1906 (Figs. 15, 16) from New Caledonia, Rec. Deplanche, ex coll. Fauvel (IRSNB), (CoOls, 19931 male, from New Caledonia, Ile d'Art, ex coll. Fauvel (IRSNB); 1 male, Aoupinié, rainforest, Malaise trap, 3/23-XI-2001, C. BURwell, G. MonTEITH leg. (QMNH); 1 male, Sarraméa, Col d'Amieu, XI/XII-2005, (QMNH); 1 male, New Caledonia, Forêt Nord, 3XII-2004, J. Burwell \& J. WRIGHT leg. (QMNH); one male, New Caledonia, Mt. Do, 800 m., 5-XI-2008, M. WANat leg. (MNHNU); one male from New Caledonia, Mt. Panié, 1200 m., 3-II-2004, M. WANAT leg. (MNHNU); one male from New Caledonia, Farino, 200m. at light, 4-XI-2010, M. WANAT leg. (MNHNU); one female from New Caledonia, Mt. Panié, east face. Malaise trap, 1320 m, 05-XII/16-XII-1990. ORSTOM-MNHN.MAE (MNHN); one female from New Caledonia, Mt. Panié, east face, Malaise trap, $1320 \mathrm{~m}, 05$ XII/16-XII-1990, M. Baylac, Th. Bourgoin, J. Bickel, L. Bonnet de Larbugne, J. Chazeau, J. DugSdale and R. Raven leg. ORSTOM-MNHN.MAE (in. MNHN); one female from New Caledonia, Hermitage, XI-1939, ex coll. Capit. QUOD (Don de Mme. JAUBERT) (MNHN); three females from New Caledonia (S), 22-17200/106.7611, Bois du Sud 220 m., day beating, 18-X-2008, M. WANAT leg. (MNHNU); one female from New Caledonia, Kogi Mts. 340 m., roadside, ex Hibbertia lucens BRONGN. et GRIS, 25-X-2008, M. WANAT leg. (MNHNU); one female from Mt. Mandjélia, 700-780 m, 21-XI-2008, M. WANAT leg. (MNHNU); Aoupinié, $700 \mathrm{~m}$, above a gravel pit, 28-XII-2008, M. WANAT leg. (MNHNU); Nouvelle Calédonie; Sarraméa, col d'Amieu, battage XII.2005 Cazéres et Mille (IAC et CJS); Nouvelle Calédonie ; Farino, V-2008, lampe UV, T. SALESNE leg. (coll. IAC et CJS). 

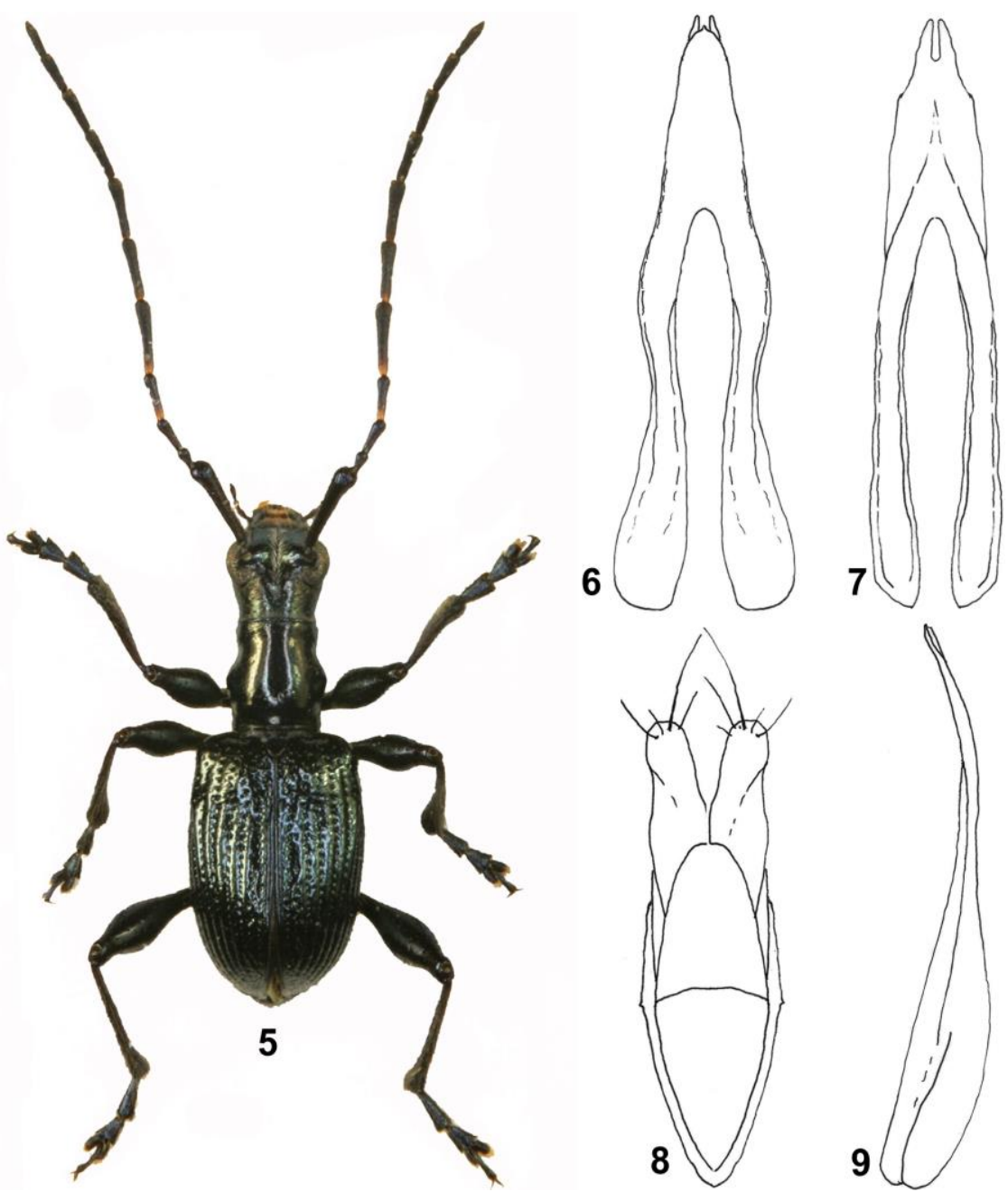

Figs. 5-9. Amphoecus metallicus MONTROUZIER, 1861: 5 - male, 6 - aedeagus, dorsal view, 7 - aedeagus, ventral view, 8 - tegmen, dorsal view, 9 - aedeagus, lateral view.

Description of male. - Length $5.2 \mathrm{~mm}$, width $1.6 \mathrm{~mm}$. Body shiny black with metallic reflections that are usually bronze on head and pronotum. Elytra, legs and antennae shiny black, antennal segments first to third with metallic reflections, segments fourth to sixth orange at the base.

Head large and rhomboidal, eyes not very prominent, microfaceted, feebly emarginate. Antennal bases broadly separated and not very prominent. Entire frons furrowed by a longitudinal depression bordered on both sides by short silver setae. Neck short and broad 
with very few sparse fine punctures. Frons broad, smooth, transversally furrowed. Labrum densely punctate at the base, orangish, smooth at the anterior margin. Epistome testaceous, trapezoidal. Palpi long and slender. Antennae long and slender reaching elytral apex in males. Scape long and pyriform with apex strongly widened, bearing long brown setae, the same as the second and third antennal segments. The third segment is much shorter than the scape, the fourth almost equal to the third, the fifth as long as the scape, the remaining segments progressively decreasing in length.

Pronotum cylindrical, almost as long as wide (ratio: $5.2 \times 5$ ), anterior and posterior margins finely bordered, sides sinuate and narrowed in the anterior third, widened in the middle. The entire disc smooth and shiny with very sparse fine punctures. Scutellum short, sides arched, apex rounded. Prosternum long and narrow with procoxal cavities bordered and prolonged towards the posterior border; the anterior half smooth and shiny, bearing very sparse fine golden setae; the posterior half is strongly punctate and has long golden setae. Prosternal process laminate, very short, not reaching the posterior part, leaving procoxal cavities open. Mesosternum quadrate, narrow and bordered at the anterior margin, very finely punctate medially and forming a finely bordered mesosternal process.

Elytra short, sides arched, rounded after apical quarter. Elytral suture finely bordered. Discal region depressed in the basal third and very convex in the apical half, particularly in females. Humeri rounded and barely protruding. Elytral grooves formed by coarse punctures that are longitudinally aligned, much more prominent in the anterior half than in the posterior half. Interstriae flattened, smooth and shiny in the anterior half, weakly convex posteriorly. Epipleurae narrow, smooth and shiny. Mesosternum short and broad, with dense white tomentum at both sides. Metasternum short and broad, also with dense white tomentum, particularly the metaepisternae which are entirely clothed in tomentum. Abdominal ventrites broad and short, finely punctate and bearing sparse golden setae. Short slender legs, femora widened in the middle, tibiae short and dilated at the apex, protibiae weakly arched, all legs covered in sparse long brown setae. Tarsi short and flattened, except for the oniquidium. Claws divaricate.

Male copulatory organ with short aedeagus, slightly arched, apex deeply forked at the ventral lamina, which is longer than the dorsal lamina. Tegmen rhomboidal, long and narrow; lateral parameres short and broad, bearing a long apical flagellum. Endophallus short and solely chitinised on the apical lobe (Figs. 6, 7, 8, 9).

Description of female. - Length 5-7 mm, width 2-2.5 mm. Body bluefish-black, almost purple, satiny, slightly metallic matt; legs and antennae brown; antennal segments fifth and base of sixth orange. Elytra of females usually a more intense purple than in males. In some specimens the pronotum is a slightly bronze colour. 


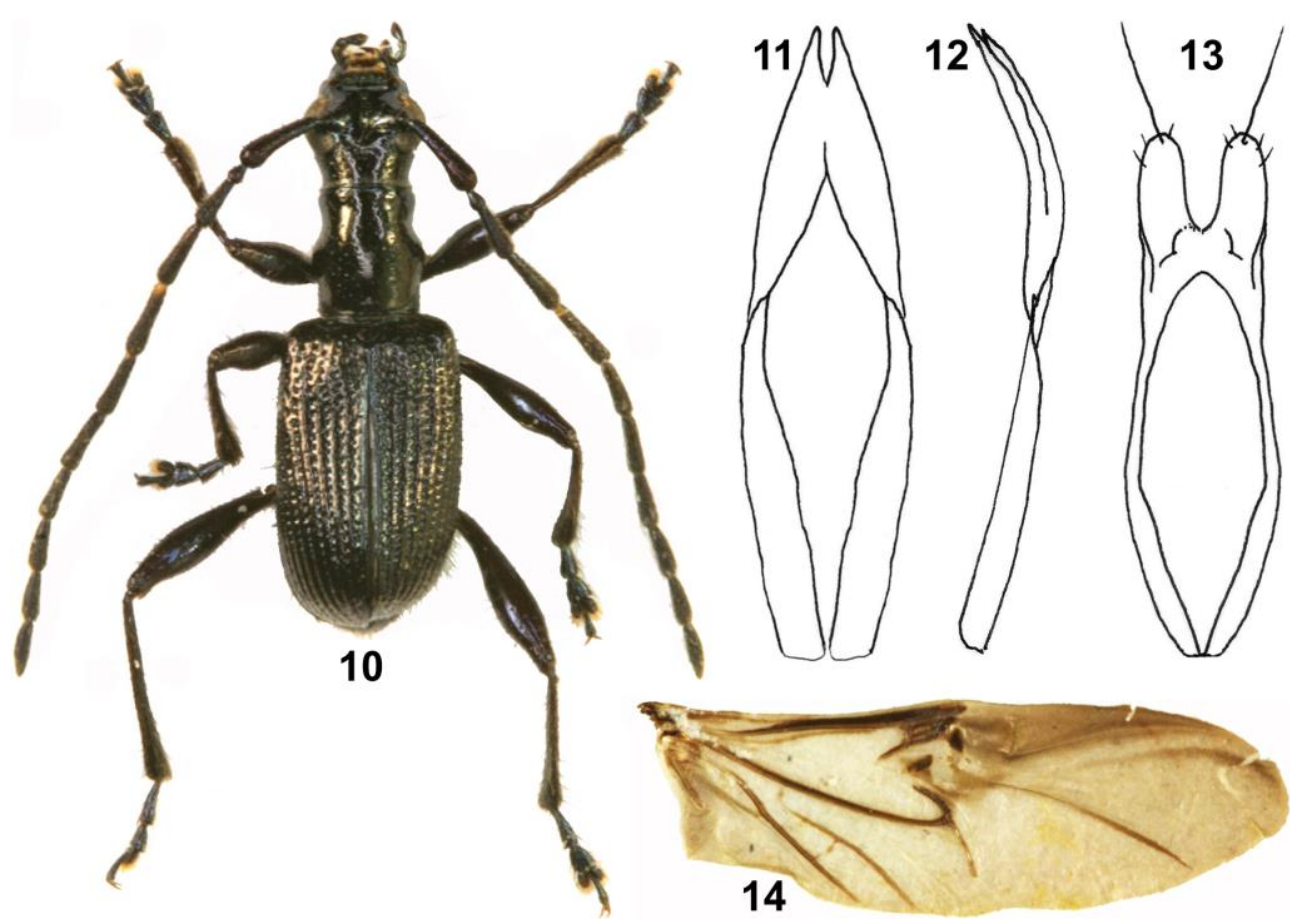

Figs. 10-13. Amphoecus wanati sp. n., holotype: 10 - male, 11 - aedeagus, ventral view, 12 - aedagus, lateral view, 13 - tegmen, dorsal view. 14 - hind wing of Amphoecus metallicus MONTROUZIER, 1861.

Head large, rhomboidal, elongate, neck very broad. Eyes weakly prominent and feebly emarginate around the antennal insertion. Antennae long and slender, all segments cylindrical except for the scape which is long and widened at the apex, generally longer in females than in males. The first four antennal segments are bluefish black and bear long brown setae, the fifth is generally as long as the third and fourth together. Palpi long and slender with the last segment dilated at the apex, which is obliquely truncate.

Pronotum cylindrical, distinctly longer than wide (ratio females: $6.5 \times 4.5$ ). Anterior and posterior margins finely bordered; sides sinuate, narrowed in the anterior third and widened in the middle. Discal region not punctate, very fine transverse striation, in males often presenting some small sparse punctures.

Short broad elytra, sides strongly arched (ratio females: 7 x 5.5 / 9.5 x 8), widely rounded beyond the posterior half and weakly acuminate at the apex. Humeri rounded and strongly protruding. Discal region depressed basally and very convex in the posterior half, elytra are dilated forming a characteristic strong bulge, suture finely bordered. The grooves 
are formed by longitudinal lines of punctures, rather inconspicuous at the base and deeper in the posterior half. Almost all elytral grooves terminate in the apical half of the suture owing to the prominently convex elytra. Interstriae flattened in the basal area and rib-like in the posterior half. Seventh interstriae forked forming a strong oblique rib that separates the discal region from the lateral slope. Epipleurae very narrow and slender. Abdominal ventrites transverse, finely punctate and with sparse pubescence. Short slender legs, profemora and mesofemora weakly dilated in the middle, metafemora dilated in the apical third.

Remarks. - This species was described by MONTROUZIER (1861) based on a specimen from the forest of l'Île d'Art located at the northern tip of New Caledonia. According to TAVAKILIAN \& Chevillotte (2012) the holotype should be in the Paris Museum collection (MNHN). However, we have been unable to locate this holotype despite our frequent visits to this institution. It is very probable that the specimen in the Brussels collection is the MONTROUZIER type that FAUVEL (1906) studied, but the size given by MONTROUZIER $(7 \mathrm{~mm})$ does not match this specimen, which is only $5 \mathrm{~mm}$ long. This species would be distributed throughout almost the entire northern half of Grand Terre.

Biology. - The A. metallicus specimens collected by M. WANAT in Kogi Mts., $340 \mathrm{~m}$. (25-X-2008) were collected from flowering plants of the Dilleniacea Hibbertia lucens BRONG \& GRIS ex SEBERT \& PANCHER, where it coexists with the Apionidae curculionid Megatracheloides chloris (FAUST, 1889) which it mimics, with the strongly bulging posterior half of the elytra (WANAT 2008). The elytra have very conspicuously punctured grooves and a bright metallic blue colouration (WANAT pers. comm.). This mimicry is probably due to the fact that the apionid is very hard. It is therefore not often hunted because many predators are unable to chew it (Figs. 17, 18).

\section{Amphoecus wanati sp. n. (Fig. 10)}

Materials examined. - HOLOTYPE male $4.8 \mathrm{~mm}$ long, $1.2 \mathrm{~mm}$ wide from New Caledonia (S), Pic du Pin (base) $280 \mathrm{~m}, 22-\mathrm{X}-2008$, M. WANAt leg. (MNHU); PARATYPES: one male from Forêt Cachee, 250-340 m, beating, 26-X-2008, M. WANAT leg. (MNHNU); one male and two females from New Caledonia (S), Pic du Pin (base) 280 m, 22-X-2008, M. WANAT leg. (MNHNU). 

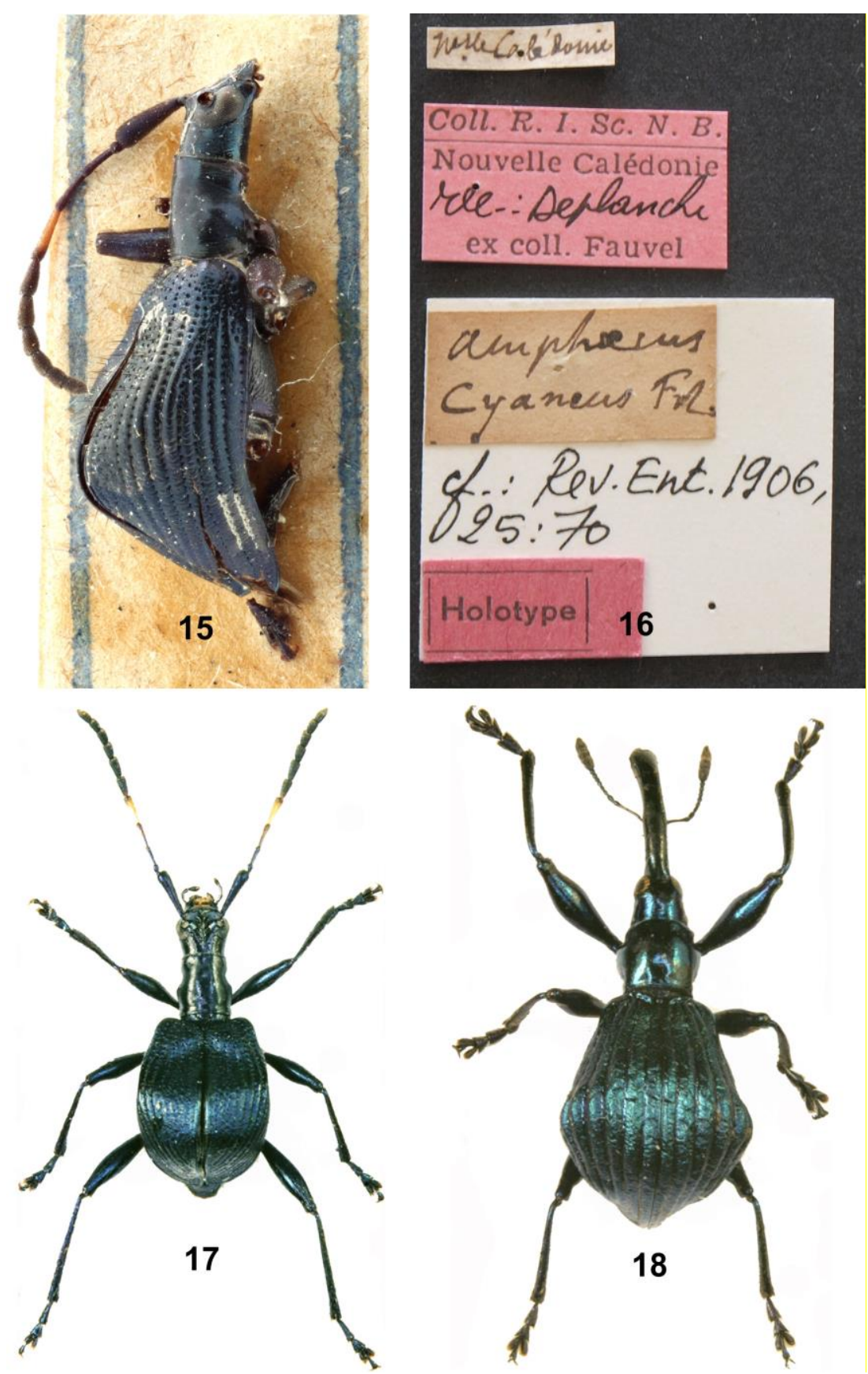

Figs. 15-18. 15 - “Amphoecus cyaneus" FAUVEL, 1906, holotype female, 16 - labels of holotype A. cyaneus, 17 - Amphoecus metallicus female, 18 - Megatracheloides chloris (FAUST, 1889), Coleoptera, Apionidae. 
Description. - General body colour shiny black with weak greenish metallic reflections on head and pronotum, legs shiny brown, antennae brown with antennal segments third to sixth entirely black.

Head elongate, large; eyes microfaceted, the lower lobe twice as long as the upper lobe; interantennal space depressed, longitudinally furrowed and bearing golden setae. Posterior part of head forming a stout neck, finely punctate and sometimes finely striate. Frons with a deep transversal furrow, labrum metallic green at the base and yellow at the apex. Epistome trapezoidal, bearing short golden setae. Antennae long and slender, antennal segments cylindrical except for the scape which is long and thickened apically, roughly punctate and slightly arched. The second antennal segment is short, slightly longer than wide, the third is half as long as the scape, the fourth and fifth longer than the third, the remaining decrease progressively in length.

Pronotum cylindrical, slightly longer than wide (ratio: $4.5 \times 3.4$ ) anterior and posterior margins finely bordered; sides sinuate, narrowed in the anterior fourth and widened in the middle forming a weak lateral protuberance. Discal region smooth, shiny, with very sparse small punctures and long brown setae. Scutellum elongate, parallel, and apex rounded. Prosternum long and narrow, bordered; prosternal process laminate, very short, hardly visible; procoxal cavities open behind.

Elytra short and parallel, slightly rounded from the apical fifth; humeri rounded and weakly protruding. Elytral suture finely bordered beyond the apical third. Disc flattened, presenting longitudinal striae formed by punctures that are larger in the anterior half than in the posterior half; the interstriae are smooth and shiny. Mesosternum short and broad, finely bordered; mesosternal process broad. Apical third of elytra rather bulging, particularly in females where it forms a prominent gibbosity. Epipleurae wide, smooth and shiny. The entire elytral surface is covered in very sparse long brown setae. Metasternum subquadrate, smooth and shiny with very sparse fine punctures and long decumbent golden setae. Metaepisternae long and narrow with decumbent grey tomentum.

Male copulatory organ with a short aedeagus, slightly arched; apex forked in the middle forming two lobes; the dorsal lamina short and acuminate. Endophallus long and narrow with two basal sclerites, median lobe bare and apical lobe with a region of dense chitinised scales (Figs. 11, 12, 13).

Etymology. - We dedicate this notable species to its discoverer, the eminent Polish specialist Prof. Dr Marek WANAT, from the Natural History Museum of Wrocław University. 


\section{REFERENCES}

AuriviLlius C. 1921. Cerambycidae: Lamiinae. [in:] S. SCHENKLING (ed.). Coleopterorum Catalogus, pars 73, vol. 23. W. Junk, Berlin, 1-322.

Breuning S. 1945. Études sur les Lamiaires (suite). Treizième Tribu: Gnomini Thomson. Novitates Entomologicae, 137/138 supplement 16: 525-535.

BREUNING S. 1951. Notes systematiques sur les longicornes de Nouvelle Calèdonie.-I. Institut royal des Sciences naturelles de Belgique. Bulletin 27(32): 1-24.

Breuning S. 1962. Catalogue des Lamiaires du Monde (Col. Céramb.). 6. Lieferung. Verlag des Museums G. Frey, Tutzing bei München, 387-459.

Broun T. 1893. Manual of the New Zealand Coleoptera. Parts V, VI, VII. New Zealand Institute, Wellington.

Cools J. 1993. Liste du matériel typique conservé dans les collections entomologiques de l'Institut royal des Sciences naturelles de Belgique. Coleoptera, Cerambycoidea, Cerambycidae. VIII. Sous-famille des Lamiinae. Documents de travail de l'I.R.Sc.N.B. 74: 61.

FAUVEl A. 1906. Faune analytique des coléoptères de la Nouvelle-Calèdonie. $4^{\text {a }}$ partie (1). Revue d'Entomologie 25: 29-99.

Hayashi M. 1961. Cerambycidae from New Caledonia (Col.) Part I. Bulletin of the Osaka Museum of Natural History 13: 7-65, 3 pl.

HelleR K.M. 1917. Die Käfer von Neue Caledonien und den benachbarten Inselgruppen. [in:] F. SARAsIn, J. RouX (eds.). Nova Caledonia. Forschungen in Neu-Caledonien und auf den LoyaltyInseln. 2 Zoologie [1916]. C.W. Kreidel, Wiesbaden, 288-297, pl. X-XI.

Hudson G.V. 1934. New Zealand beetles and their larvae. An elementary introduction to the study of our native Coleoptera. Ferguson \& Osborn Publ., Wellington.

HutTon F.W. 1904. Index Faunae Novae Zealandiae. Dulau Co., London.

LACORDAIRE J.T. 1869. Histoire Naturelle des Insectes. Genera des Coléoptères ou exposé méthodique et critique des tous les genres proposés jusqu'ici dans cet ordre d'insectes., Famille des Longicornes (suite). Paris Librairie Encyclopedique de Roret 9(1): 1-409.

Leschen A.R., Lawrence J.F., Kuschel G., Thorpe S., WAng Q. 2003. Coleoptera genera of New Zealand. New Zealand Entomologist 26(1): 15-28.

MontrouZIER J.X.H. 1861. Essai sur la fauna entomologique de la Nouvelle-Calèdonie (Balade) et des Îles des Pins, Art, Lifu etc. Coléoptères. Annales de la Société entomologique de France ser. 4 1: 265-306, pl. 5.

Sudre J., Vives E., Cazères S., Mille C. 2010. Contribution à l'étude des Cerambycidae (Coleoptera) de la Nouvelle-Calédonie - $1^{\text {a }}$ partie: sous-familles des Lamiinae. Mémoires de la Société Linnéenne de Lyon 1: 1-77.

Tavakilian G., Chevillotte H. (2012). Titan: base de données internationales sur les Cerambycidae ou Longicornes. Internet: http://lully.snv.jussieu.fr/titan. (Accessed on March 2016)

Wanat M. 2008. The Apionidae (Coleoptera: Curculionoidea) of New Caledonia. Genus Megatracheloides. [in:] P. GRANDCOLAS (ed.). Zoologia Neocaledonica 6. Biodiversity studies in New Caledonia. Mémoires du Muséum national d'Histoire naturelle 197: 297-321. 
Received: 6 March 2016

Accepted: 30 March 2016 